\author{
Dominika Hapek \\ Uniwersytet Ekonomiczny w Krakowie \\ dominika.hapek@phd.uek.krakow.pl \\ (D) https://orcid.org/0000-0001-6826-254X
}

\title{
Wykorzystanie nowych technologii jako element współczesnego marketingu hotelu niezależnego
}

\section{Streszczenie}

Wykorzystanie nowych technologii stało się integralną częścią otaczającego nas świata w każdej dziedzinie życia. Trend ten przeniósł się na płaszczyznę funkcjonowania obiektów hotelowych, w których współczesny marketing jako podstawowe narzędzie pozyskiwania klientów nierozerwalnie połączony jest z zastosowaniem nowych rozwiązań w budowaniu przewagi konkurencyjnej. Dotychczasowe badania opierały się na ocenie i analizie popytowej strony użycia nowych technologii w branży turystycznej z wyszczególnieniem obiektów hotelowych. Celem rozdziału jest określenie wykorzystania nowych technologii jako elementu współczesnego marketingu hoteli niezależnych na przykładzie wybranych hoteli województwa małopolskiego. Badania pilotażowe zostały przeprowadzone na podstawie wywiadów z menedżerami hoteli metodą analizy studium przypadków. Wyniki potwierdziły, że urządzenia mobilne i media społecznościowe stały się głównymi kanałami marketingu badanych hoteli.

\section{Wprowadzenie}

Transformacyjne skutki technologii cyfrowych są widoczne w prawie wszystkich branżach i środowiskach biznesowych (Chanias i in., 2019). W szczególności technologia informacyjna przekształciła rynek turystyczny i hotelarski (Sigala, 2018). W przemyśle turystycznym, zwłaszcza w sektorze hotelowym, efektywne wykorzystywanie nowych technologii jest podstawą w planowaniu strategii zarządzania. Zmieniający się system dystrybucji spowodowany rosnącą dominacją 
kanałów dystrybucji online, rozwój modeli biznesowych opartych na platformie ekonomicznej oraz stale rosnący wpływ treści generowanych przez użytkowników zmusiły hotele do ponownego rozważenia nowych technik zarządzania dochodami (z ang. Revenue Management RM) i strategii cenowej (Cross, 2016).

Możliwości technologii cyfrowych nie ograniczają się jednak do funkcji informowania i pośredniczenia w procesie rezerwacji. Technologie te umożliwiają szybkie i tanie pozyskiwanie danych dotyczących preferencji konsumentów oraz ich cech społeczno-demograficznych. Dostępność tego rodzaju danych pozwala na dopasowanie oferty do potrzeb zróżnicowanych grup odbiorców. Jest ona również warunkiem koniecznym do prowadzenia efektywnych, skalowalnych i spersonalizowanych działań marketingowych.

Ze strony klientów szybkie i łatwe rozwiązania mobilne są opracowane i opublikowane w literaturze przedmiotu. Kompleksowy przegląd pokazuje, że większość badań koncentruje się na kontekście doświadczeń turystycznych i branży hotelarskiej. Nieproporcjonalnie więcej badaczy skupiło się na konsumentach niż na dostawcach (Law, 2018).

W literaturze polskiej i zagranicznej wiele miejsca poświęcono na badania marketingowe hoteli z punktu widzenia konsumenta, analizy hoteli wykorzystujących technologię. „Najczęściej technologia informatyczna używana jest we wszelkiego typu systemach rezerwacji oraz informacji, i w tym zakresie jest też najczęściej omawiana jako przykład innowacyjny" (Bednarczyk, Handzel, 2007). Autorka skupiła się przede wszystkim na hotelach niezależnych, które niejednokrotnie nie dysponują takim kapitałem, zespołem pracowników - specjalistów, brandem jak międzynarodowe sieci hotelowe, co na starcie utrudnia im walkę o zainteresowanie klienta, w dodatku wymusza na nich większą kreatywność działania przy wykorzystaniu dostępnych form przekazu. Autorka przeprowadziła pilotażowe badania na wybranej grupie hoteli, inspirując się badaniami przeprowadzonymi w 23 luksusowych hotelach w Jordanii (Alrawadieh i in., 2020).

Dokładna kwerenda literatury pozwoliła stwierdzić, że brakuje publikacji związanych $z$ omawianym tematem poświęconych polskiemu rynkowi, co stanowiło jedną z głównych przesłanek podjęcia badań. Wybór tematyki nie jest przypadkowy. Poprzedzono go analizą literatury przedmiotu, wnikliwą obserwacją podmiotów funkcjonujących na rynku usług hotelowych oraz przedstawiono wnioski dotyczące wpływu zastosowania nowych technologii jako elementu marketingu hoteli niezależnych. Celem pracy jest określenie stopnia wykorzystania nowych technologii jako elementu współczesnego marketingu hoteli niezależnych.

\section{Przegląd literatury}

Rosnące uzależnienie od technologii cyfrowej jest dostrzegane $\mathrm{w}$ wielu branżach, turystyka nie jest wyjątkiem (Buhalis i in., 2019). Wykorzystanie nowych technologii stało się niezbędne, aby firmy mogły osiągnąć kluczowe cele biznesowe obejmujące poprawę jakości usług, redukcję kosztów, uzyskanie przewagi konkurencyjnej, tworzenie wiedzy i maksymalizację przychodów (Camilleri, 2018). Van 
der Wagen i Goonetilleke (2008) podkreślają, że „W dokonywaniu transformacji technologii informatycznych branża turystyczna wyprzedziła wszystkie inne gałęzie przemysłu". Rozwój technologii informacyjno-komunikacyjnych umożliwił digitalizację informacji (Kachniewska, 2017).

Poziom wykorzystania danych i technologii cyfrowych do celów analitycznych i marketingowych przez polskie przedsiębiorstwa turystyczne należy do najniższych w Europie. Wyniki takie daleko odbiegają od średniej państw europejskich. Również poniżej średniej europejskiej Polska wypada pod względem odsetka przedsiębiorstw wykorzystujących w swojej działalności media społecznościowe - rozwiązanie takie stosuje $67 \%$ polskich firm w porównaniu ze średnim wynikiem państw Unii Europejskiej wynoszącym 74\% (Czernecki i in., 2020).

Znaczący wpływ na rozwój operacyjny sektora usług hotelarskich wywierają innowacyjne narzędzia i kanały dystrybucji. Współcześnie $\mathrm{w}$ dystrybucji online dominują: internetowe biura podróży (OTA), platformy rezerwacyjne oraz urządzenia mobilne (smartfony $\mathrm{i}$ aplikacje) (Alrawadieh $\mathrm{i}$ in., 2020).

Mnogość ofert, które dziennie klient widzi na ekranie telefonu, sprawia, że robi to automatycznie, nie skupiając specjalnie uwagi na treściach. W świecie zdominowanym przez smartfon, w którym kupujący ma automatyczny dostęp do wyszukiwarki ofert, porównywarki cen, portali opiniotwórczych, z punktu widzenia marketingu hotelu ważne jest zaistnienie w świadomości odbiorcy i wyróżnienie swojej oferty. Dlatego też w XXI w. tradycyjny marketing już nie wystarczy. Nowoczesne ujęcie marketingu wychodzi poza typową działalność handlową, skupia się bardziej na formie kontaktu między ludźmi, umożliwiając dotarcie do klienta różnymi kanałami dystrybucji, ważne, żeby były one twórcze, innowacyjne $\mathrm{i}$ oryginalne.

Kurletko (2013) podjęła próbę „zaprezentowania oddziaływania nowych technologii komunikacyjno-informacyjnych i innych na zarządzanie przedsiębiorstw turystycznych., wskazując na możliwość przetwarzania danych i redukcję kosztów".

\section{Metodyka badań}

Celem pracy jest określenie wykorzystania nowych technologii jako elementu współczesnego marketingu hoteli niezależnych na przykładzie wybranych hoteli województwa małopolskiego. Badania pilotażowe zostały przeprowadzone na podstawie wywiadów z menedżerami hoteli metodą analizy studium przypadków.

Rozmówcy zostali poproszeni o wskazanie elementów nowoczesnego marketingu wykorzystywanego $\mathrm{w}$ działaniach promocyjnych, tworząc spersonalizowane kampanie w mediach społecznościowych (social mediach), docierając do poszczególnych grup docelowych. W badaniu skupiono się na formach wykorzystania informacji o kliencie, pozyskanych za pomocą CRM oraz przez pracowników recepcji. Drugim ważnym zagadnieniem w wywiadzie było wykorzystanie aplikacji mobilnych synchronizujących Booking.com i Facebook, które ułatwiają gościom dokonywanie rezerwacji usług bezpośrednio z Facebooka. Istotną kwestią było, 
w jaki sposób hotele używają bazy mailingowej, jakie działania podejmują, budując relacje $z$ gościem jeszcze przed przyjazdem, w trakcie pobytu oraz po wyjeździe. Autorka pogrupowała pytania w wywiadzie w 5 kluczowych jej zdaniem zakresów tematycznych:

- kampanie w mediach społecznościowych,

- wykorzystanie aplikacji mobilnych,

- kampanie reklamowe z udziałem fanów i celebrytów,

- tworzenie bazy mailingowej,

- dodatkowe funkcjonalności na stronie internetowej hotelu.

\section{Wyniki badań}

Badania pilotażowe w zakresie wykorzystania nowoczesnych technologii jako elementu współczesnego marketingu wykonano na grupie 15 menedżerów niezależnych hoteli 3-, 4- i 5-gwiazdkowych na terenie województwa małopolskiego. Badany okres obejmował miesiące od lipca do grudnia 2019 r. Autorka przeprowadziła badanie w listopadzie-grudniu 2020 r., wybrała technikę wywiadu na podstawie kwestionariusza wywiadu $z$ kafeterią półotwartą. Do badania zostało zaproszonych 20 menedżerów hoteli, z czego 15 przyjęło zaproszenie, 5 odmówiło.

Wszyscy respondenci odpowiedzieli na każde z zadanych pytań. Wśród rozmówców było 10 kobiet i 5 mężczyzn. Zdecydowana większość była w przedziale wiekowym 31-35 lat, 3 osoby powyżej 40. roku życia i $2 \mathrm{w}$ wieku 26-30 lat. W zakresie wykształcenia 9 badanych wskazało wykształcenie wyższe magisterskie, a 6 osób licencjat/inżynier. Większość rozmówców wskazała miejsce zamieszkania jako miasto powyżej 500 tys. mieszkańców, 3 osoby zadeklarowały zamieszkanie na terenach wiejskich. Hotele 3-gwiazdkowe jako miejsce pracy wskazało 9 menedżerów, w hotelu 4-gwiazdkowym pracowały 4 osoby i 2 wskazały na pracę w hotelu 5-gwiazdkowym.

Menedżerowie kilku obiektów prosili o anonimowość, dlatego na potrzeby publikacji hotele oznaczono w kolejności od A do O.

Respondenci zostali poproszeni o udzielenie informacji dotyczących wykorzystania nowych technologii w działaniach marketingowych. Najczęściej pojawiającą się odpowiedzią było posiadanie strony internetowej hotelu. W 7 hotelach można dokonać rezerwacji usługi bezpośrednio na stronie www hotelu, pozostałe 8 obiektów dysponowało formularzem z zapytaniem o dostępność wolnych pokoi w wybranym terminie.

„Najczęściej pytania przesyłane przez nasz formularz dotyczą terminów na przyjęcia okolicznościowe, wesela, wynajem sali konferencyjnej na szkolenia lub eventy. Goście zdecydowanie częściej kontaktują się z hotelem telefonicznie. Są to najczęściej zapytania o rezerwację noclegu na ten sam dzień" - mówi menedżer hotelu N.

Wśród wszystkich badanych hoteli tylko 2 mają stronę internetową dostosowaną do urządzeń mobilnych, pomimo że większość rezerwacji dokonywanych 
przez klientów w XXI w. odbywa się przy użyciu smartfona. Umożliwiając gościom rezerwację pokoju lub usługi bezpośrednio na stronie internetowej hotelu, obiekty ograniczają udział OTA i GDS w procesie rezerwacji. „Przez brak możliwości dokonania rezerwacji noclegów bezpośrednio na stronie hotelu płacimy wyższe faktury prowizyjne pośrednikom, np. OTA" - stwierdził menedżer hotelu H. System rezerwacji w formie aplikacji mobilnej, np. IdoBooking, umożliwiającej dokonywanie szybko i prosto rezerwacji bezpośrednio na Facebooku, nie jest używany w badanych obiektach.

Aplikacje mobilne są kosztownym wydatkiem, który często wykracza poza możliwości hotelu niezależnego finansowanego przez prywatnego właściciela. „Właściciel hotelu niechętnie inwestuje pieniądze w dodatkowe aplikacje na urządzenia mobilne, które ułatwiają i mogłyby wspierać codzienną pracę i zarządzanie obiektem" - skomentował menedżer hotelu J.

Wszystkie hotele miały swój fanpage na Facebooku, zróżnicowanie pojawiło się w codziennych aktywnościach i prezentowanych treściach. Hotele miały zaplanowaną spójną strategię promocji dedykowaną mediom społecznościowym. W jednym z obiektów wszystkie kampanie prowadzi agencja reklamowa, w pozostałych 14 zajmują się tym pracownicy recepcji lub menedżer.

Zapytano menedżerów, jak wykorzystują siłę Facebooka jako element marketingu i reklamy o dalekich zasięgach. W tym miejscu najczęściej pojawiały się odpowiedzi dotyczące planowania kampanii. „Prowadzimy długoterminowa przemyślaną strategię z ułożonym kalendarzem publikacji postów, dopracowaną grafiką i treściami spójnymi z aktualnymi działaniami obiektu" - przyznał menedżer hotelu C. „Skupiamy się na dodawaniu wyłącznie postów z informacją o ofercie specjalnej, rabatach, obniżkach cen. Robimy dość regularnie promocje, o których informujemy za pośrednictwem social mediów" - tłumaczył menedżer hotelu P. W odpowiedziach menedżerów najczęściej występowały płatne reklamy na Facebooku jako kampanie marketingowe tworzone w okresie lipiec-grudzień 2019 r. Pojawiły się też hotele, które nie korzystały z tej formy przekazu. „Nie tworzyliśmy płatnych kampanii na social mediach, ponieważ ze względu na lokalizację mamy wysoki wskaźnik obłożenia przez cały rok" - mówił menedżer hotelu B.

Najczęściej hotele robią krótkie posty na portalu Facebook. Dzięki skomplikowanym algorytmom Facebook skutecznie wspiera działania promocyjne hoteli, które mają dużą ilość polubień i komentarzy pod swoimi postami, dzięki czemu zwiększa się zasięg publikowanych wiadomości na fanpage'u hotelu. Turyści chętnie obserwują hotele, w których regularnie aktualizowana jest lista wydarzeń. Dodatkowo udostępnianie w mediach społecznościowych na żywo relacji z wydarzeń w hotelu stało się bardzo popularne i często wykorzystywane. Wystarczy nakręcić smartfonem lub tabletem krótki film i dodać na Facebook lub Instagram, oznaczając osoby biorące udział w tym wydarzeniu. „Z chęcią pokazujemy klientom wydarzenia w hotelu. Zwykle to ja nagrywam krótki film - relację z każdego eventu. Często robię zdjęcia nowości w karcie menu restauracji i dodaję na social media. Wiem, jak ważne jest bycie obecnym w sieci. Klienci podczas meldowania proszeni są o polubienie naszego fanpage'u na Facebooku, tak zdobywamy like. 
Goście w zamian otrzymują voucher zniżkowy do naszej restauracji do wykorzystania w trakcie pobytu" - tłumaczy menedżerka hotelu K.

Żaden z hoteli nie ma kanału na Youtube i konta na kanale TicTok. Znikoma część menedżerów dostrzega potrzebę komunikowania się z klientami za pośrednictwem Instagrama.

Wyniki badań wskazują, że obiekty położone ściśle w centrum miasta Krakowa nie inwestują w kampanie reklamowe, ponieważ idealna lokalizacja zapewnia im gości. Żaden $z$ hoteli nie korzysta z usług celebrytów, fanów mających dużą liczbę odbiorców na kanałach You Tube, Instagram czy Facebook czy w celu promocji. Live i nagrania na żywo zdarzały się dość często w 4 obiektach, głównie z celebrytami i popularnymi aktorami nocującymi w hotelu.

W grupie menedżerów hoteli 3-gwiazdkowych nie są prowadzone analizy pozyskanych danych o klientach. Karty meldunkowe zawierają pole e-mail, niemniej recepcjoniści rzadko proszą o ich uzupełnianie. Wśród menedżerów hoteli położonych poza Krakowem w miejscowościach ościennych często pojawiało się stwierdzenie, że pozyskiwanie e-maili klientów nie jest potrzebne, ponieważ nie prowadzili i nie planują prowadzenia kampanii wysyłki newslettera lub spersonalizowanych ofert. W hotelach 4- i 5-gwiazdkowych trend jest zupełnie odmienny. Położony jest bardzo duży nacisk na marketing lojalnościowy, stali klienci otrzymują bonifikaty oraz $\mathrm{z}$ wyprzedzeniem informowani są o najnowszych ofertach hotelu wysyłanych za pośrednictwem e-maila. „Wysyłka e-maili w naszym hotelu prowadzona jest przez pracowników recepcji lub dział marketingu" - wyjaśnił menedżer hotelu A.

\section{Zakończenie}

Reasumując, wykorzystanie nowych technologii jako elementu współczesnego marketingu $\mathrm{w}$ badanych przez autorkę hotelach może pomóc stworzyć skuteczny i efektywny plan działania i zautomatyzować pracę personelu. Menedżerowie rozumieją potrzebę inwestowania w strony internetowe dostosowane do urządzeń mobilnych oraz aplikacje mobilne, jednak niechętnie korzystają z tego rodzaju aplikacji głównie przez wysokie koszty inwestycji i niepewny zwrot. Zauważyć można zróżnicowanie w podejściu do działań marketingowych pomiędzy hotelami 3- i 5-gwiazdkowymi. Najczęściej stosowaną praktyką jest umieszczanie postów lub filmów w mediach społecznościowych ze zdjęciami popularnych aktorów czy celebrytów, którzy nocują w hotelu. Żaden z badanych hoteli nie współpracuje na stałe ze znanymi i popularnymi w mediach społecznościowych celebrytami czy fanami, związane jest to przede wszystkim z ograniczonym budżetem. Menedżerowie hoteli prywatnych wykazują się pomysłowością, kreatywnością i mają większą możliwość kontaktu z gościem i spersonalizowania oferty. Cechą wspólną wszystkich obiektów jest sprzedawanie usług i ofert pakietowych (nocleg plus gastronomia lub SPA) za pomocą swojej strony internetowej. Każdy $z$ badanych hoteli ma własną stronę internetową, ale tylko hotele 5-gwiazdkowe 
z badanej grupy mają stronę www dostosowaną do urządzeń mobilnych, pomimo że klienci coraz częściej korzystają ze smartfona, dokonując rezerwacji.

Kluczem do zwiększenia zainteresowania menedżerów hoteli, inwestowania w nowe technologie jest używanie mediów społecznościowych oraz angażowanie fanów w celu promowania hotelu jako jeden $z$ elementów współczesnego marketingu. Zakup aplikacji mobilnych wykorzystywanych do działań promujących sprzedaż usług hotelowych i rezerwacje dokonywane bezpośrednio przez stronę hotelu będą zmniejszały koszty prowizji płaconych dotychczas pośrednikom.

Popularyzacja i szeroko pojęta dostępność w mediach społecznościowych, przy współpracy z fanami, popularnymi aktorami, celebrytami, właścicielami popularnych kanałów na YouTube czy Instagramie, będą warunkowały według autorki dalszy wzrost znaczenia elementów nowoczesnego marketingu wśród hoteli niezależnych. W świetle zaprezentowanych wyników należy uznać, że zagadnienie nowych technologii w działaniach marketingowych hoteli jest wciąż mało zbadaną i interesującą dziedziną. Przedstawione badania mają kilka ograniczeń. Jakościowe podejście badawcze, wybranie grupy hoteli niezależnych czy lokalizacja (obiekty z województwa małopolskiego) eliminuje możliwość uogólniania wyników na całą branżę hotelarską. Temat jest złożony i ważny z punktu widzenia menedżerów na etapie określania strategii działań marketingowych hoteli, wymaga pogłębienia z perspektywy pozostałych pracowników hotelu z działu sprzedaży, marketingu i IT. W przyszłości badania należy rozszerzyć m.in. o aspekty barier zastosowania współczesnego marketingu z wykorzystaniem urządzeń mobilnych w hotelach.

\section{Literatura}

Alrawadieh Z., Alrawadieh Z., Cetin G. (2020). Digital transformation and revenue management: Evidence from the hotel industry. Tourism Economics, 1-8, doi: 10.1177/1354816620901928.

Barsoux J.L., Wade M., Bouquet C. (2019). Jak wcielać w życie przełomowe koncepcje. Harvard Business Review, lipiec-sierpień: 84-97.

Buhalis D., Harwood T., Bogicevic V. i in. (2019). Technological disruptions in services: lessons from tourism and hospitality. Journal of Service Management, 30(4): 484-506.

Buhalis D., Law R. (2008). Progress in Tourism Management. Progress in Information Technology and Tourism Management - The State of e-Tourism Research. Tourism Management, 29(4): 609-623.

Camilleri M.A. (2018). The promotion of responsible tourism management through digital media. Tourism Planning \& Development, 15(6): 653-671.

Chabrzyk, Drapała, Raszkowska, Suhov, Wodzyńska (2020). Branża turystyczna w Polsce. Obraz sprzed pandemii. Polski Instytut Ekonomiczny, Warszawa.

Chanias S., Myers M.D., Hess T. (2019). Digital transformation strategy making in pre-digital organizations: the case of a financial services provider. The Journal of Strategic Information Systems, 28(1): 17-33.

Clero C., Gloton R. (1976). Twórcza aktywność dziecka. Wydawnictwa Szkolne i Pedagogiczne, Warszawa, s. 36. 
Czernicki Ł., Kukołowicz P., Miniszewski M. (2020). Branża turystyczna w Polsce. Obraz sprzed pandemii. Polski Instytut Ekonomiczny, Warszawa.

Femenia-Serra F., Gretzel U. (2020). Technologie informacyjne i komunikacyjne w turystyce 2020. Materiały z międzynarodowej konferencji w Surrey, Wielka Brytania, 8-10 stycznia 2020 r. Information and Communication Technologies in Tourism, s. 65-78.

Florida R. (2010). Narodziny klasy kreatywnej oraz jej wpływ na przeobrażenia w charakterze pracy, wypoczynku, społeczeństwa i życia codziennego. Tłum. T. Krzyżanowski, M. Penkala. Narodowe Centrum Kultury, Warszawa, s. 51.

Hjalager A.M. (2010). A Review of Innovation Research in Tourism. Tourism Management, 31: 1-12.

Jedlińska M. (2006). Wejście międzynarodowych systemów hotelowych na rynek polski a modyfikacja oczekiwań gości hotelowych. [W:] A. Rapacz (red.), Gospodarka turystyczna w regionie. Przedsiębiorstwo, samorząd, współpraca. Wyd. Wyższej Szkoły Zarządzania, Jelenia Góra.

Kachniewska M. Innowacyjne modele biznesu jako strategia przetrwania niezależnych obiektów hotelowych w warunkach polaryzacji rynku turystycznego.

Kim E., Nam D.I., Stimpert J.L. (2004). The Applicability of Porter's Generic Strategies in the Digital Age, Assumptions, Conjectures and Suggestions. Journal of Management, $30,5$.

Kisielnicki J. (2002). Systemy informatyczne jako narzędzie dla zarządzania wiedzą - efekty i bariery. Inżynieria Maszyn, R. 7, 2: 29-33.

Kuczamer-Kłopatowska S., Piekarska K. (2018). Realizacja funkcji influencer marketing w opinii influencerów i ich followersów. Zarządzanie i Finanse, Journal of Management and Finance, 16, $3 / 3$.

Kurleto M. (2013). Wpływ nowych technologii na zarządzanie przedsiębiorstwem turystycznym. Zarządzanie Publiczne, 1(21): 91-102.

Niezgoda A., Markiewicz E. (2015). Uniwersytet Ekonomiczny w Poznaniu. Zmiany w zachowaniu konsumentów na rynku turystycznym w erze społeczeństwa twórczego. Zeszyty Uniwersytetu Szczecińskiego, 865, Problemy Zarządzania, Finansów i Marketingu, 38.

Nowacki R. (2009). Rozwój usług marketingowych w Polsce a ich jakość. Handel Wewnętrzny, 2: 18.

Paraskevas A., Buhalis D. (2002). Information Communication Technologies Decisionmaking: The ASP Outsourcing Model from the Small Hotel Owner/Manager Perspective. The Cornell Hotel Restaurant Administration Quarterly, 43, 2: 27-39.

Paraskevas A., Buhalis D. (2002). Information Communication Technologies Decisionmaking: The ASP Outsourcing Mediarun, Smartfon coraz ważniejszy dla handlu. Co z pozostałymi kanałami? (www.mediarun.com/pl/digital/smartfon-coraz-wazniejszy-dla-handlu-pozostalymi-kanalami.html; dostęp: 15.01.2021).

Sigala M. (2018). New technologies in tourism: from multi-disciplinary to anti-disciplinary advances and trajectories. Tourism Management Perspectives, 25: 151-155.

Szewczuk W. (1985). Słownik psychologiczny. Wiedza Powszechna, Warszawa, s. 327.

Wagen L. van der, Goonetilleke A. (2008). Hospitality Management: Strategy and Operations. Wyd. 2. Pearson Education, Australia

Wyrwisz J. (2019). Influencer marketing w komunikacji marketingowej marki. W: M. Cisek (red.), Innowacje i cyfryzacja gospodarki. Wydawnictwo Naukowe Uniwersytetu Przyrodniczo-Humanistycznego, Siedlce, s. 79-88. 


\section{The use of new technologies as an element of contemporary marketing of an independent hotel}

The use of new technologies has become an integral part of the world around us in every area of life. This trend has reached the level of hotel facilities, where modern marketing as a basic tool for attracting customers is permanently linked with the use of new solutions in building competitive advantage. Research to date has been based on the assessment and analysis of the demand side of the use of new technologies in the tourism industry, with a special focus on hotel facilities. The aim of the paper is to determine the use of new technologies as an element of modern marketing of independent hotels on the example of selected hotels in the Małopolska province. The initial research was based on interviews with hotel managers, using the case study analysis method. The results of the research confirmed that mobile devices and social media have become the main marketing channels of the studied hotels. 